International Business and Global Economy 2018, no. 37, pp. 272-285

Biznes międzynarodowy w gospodarce globalnej 2018, nr 37, s. 272-285

Edited by the Institute of International Business, University of Gdańsk

ISSN 2300-6102

e-ISSN 2353-9496

DOI 10.4467/23539496IB.18.019.9392

Aleksandra Koźlak

Uniwersytet Gdański

\title{
Znaczenie usług transportowych w bilansie płatniczym Polski na tle tendencji w międzynarodowej wymianie handlowej
}

Ze względu na wzrost znaczenia usług w gospodarce podjęto się zbadania wielkości i struktury światowych obrotów usługami oraz ich udziału w bilansie płatniczym Polski. Szczególną uwagę zwrócono na eksport i import usług transportowych. Celem artykułu było wykazanie znaczenia usług transportowych w polskim handlu zagranicznym. Aby go osiągnąć, przeprowadzono analizę danych statystycznych dotyczących handlu światowego oraz statystyk polskiego bilansu płatniczego. Poza tym posłużono się metodami opisowymi (analiza literatury przedmiotu) oraz ogólnymi metodami badawczymi i zasadami racjonalnego rozumowania. Przeprowadzone badania pozwoliły na stwierdzenie, iż zarówno w handlu światowym, jak i w polskim handlu zagranicznym wzrasta udział obrotów usługami, przy czym udział usług w obrotach polskiego handlu zagranicznego jest o kilka punktów procentowych niższy niż średnio na świecie. Wykazano również, iż w przeciwieństwie do tendencji w handlu światowym, w Polsce następuje wzrost eksportu i importu usług transportowych. Bilans usług transportowych w polskim bilansie płatniczym jest dodatni, przy czym w największym stopniu przyczynia się do tego nadwyżka eksportu nad importem usług transportu samochodowego. Świadczy to o wysokiej konkurencyjności polskiego transportu samochodowego.

Słowa kluczowe: bilans płatniczy, handel światowy, handel zagraniczny Polski, międzynarodowy handel usługami, usługi transportowe

Klasyfikacja JEL: F10, F19, F40, F60

\section{Importance of transport services in the Polish balance of payments against the background of trends in international trade}

The paper examines the size and structure of global trade in services and their share in Poland's balance of payments. Particular attention was paid to export and import of transport services. The main purpose of the paper was to prove the importance of transport services in Polish foreign trade. Statistical data on Polish and world trade were analysed to achieve this goal. In addition, descriptive methods (analysis of literature) as well as general research methods and principles of scientific reasoning were used. The conducted research allowed to state that both in world trade and in Polish foreign trade the share of services increases, while the share of services in the Polish foreign trade turnover is by a few percent lower than the world average. It was also indicated that, in contrast to the trends in world trade, there was an increase in export and import of transport 
services in Poland. The balance of transport services in the Polish balance of payments is positive. The surplus of export over the import of road transport services constitutes a major contribution to the good result. This proves that Polish road transport is highly competitive.

Keywords: balance of international payments, world trade, foreign trade of Poland, international trade in services, transport services

JEL classification: F10, F19, F40, F60

\section{Wprowadzenie}

Handel międzynarodowy odgrywa istotną rolę w nowoczesnej gospodarce światowej. Procesy globalizacyjne przyspieszyły zmiany w rozmieszczeniu produkcji pomiędzy krajami i kontynentami, a także doprowadziły do alokacji inwestycji finansowych, co spowodowało intensyfikację międzynarodowej współpracy gospodarczej. Z punktu widzenia poszczególnych krajów handel zagraniczny przyczynia się do wzrostu PKB, wpływa na jego strukturę, prowadzi do specjalizacji produkcji, umożliwia i ułatwia postęp technologiczny. Pozwala też osiągać korzyści dzięki konkurencji i zwiększeniu wydajności, prowadząc w rezultacie do wzrostu jakości produktów i usług oraz zmniejszenia kosztów produkcji [Jaszczyński, 2016].

Procesowi globalizacji towarzyszą zmiany w sieciach komunikacyjnych, systemach transportowych, strukturach organizacyjnych przedsiębiorstw i systemach wartości, a także zmniejszanie się roli państwa w gospodarce. Rozwój ilościowy i jakościowy systemu transportowego oraz wdrażanie nowoczesnych rozwiązań w zintegrowanych łańcuchach dostaw istotnie sprzyja globalizacji powiązań gospodarczych. Sprawny transport stanowi podstawowy warunek realizacji międzynarodowych przepływów towarowych i usługi transportowe również są przedmiotem wymiany międzynarodowej.

Na tle tendencji światowych w wymianie usług przeprowadzono analizę wielkości i salda obrotu usługami transportowymi w polskim bilansie płatniczym i zmian zachodzących w tym zakresie. Celem artykułu jest określenie znaczenia usług transportowych $w$ polskim handlu zagranicznym, $w$ tym $w$ ujęciu gałęziowym.

\section{Zmiany wielkości i struktury międzynarodowej wymiany handlowej}

Charakterystyczną cechą współczesnej gospodarki światowej jest przepływ czynników produkcji między krajami i znoszenie ograniczeń w handlu międzynarodowym (eliminowanie barier taryfowych i pozataryfowych). Do liberalizacji 
handlu międzynarodowego przyczyniły się działania Światowej Organizacji Handlu (WTO) oraz znoszenie restrykcji w obrotach handlowych w ramach ugrupowań integracyjnych. Ułatwiało to dostęp do rynków innych państw i sprzyjało wzrostowi przepływów międzynarodowych towarów i usług. Wśród podstawowych czynników wpływających na rozwój handlu międzynarodowego należy wymienić również postęp technologiczny. Szybki rozwój technologii, jaki miał miejsce $w$ przemyśle przetwórczym, transporcie, telekomunikacji i informatyce, istotnie wpłynął na zwiększenie skali wymiany międzynarodowej [Rogaczewski, 2017].

Analizując wielkość międzynarodowych przepływów towarów, można zauważyć, iż na przestrzeni lat 1970-2016 dynamika handlu międzynarodowego była znacznie wyższa niż przyrost światowego produktu brutto. W okresie tym wielkość światowego eksportu towarów wzrosła ponad 50-krotnie, podczas gdy światowy produkt brutto wzrósł tylko 22-krotnie [UNCTADSTAT, 2018]. Trzema największymi światowymi partnerami w handlu międzynarodowym są UE-28, Chiny i Stany Zjednoczone. Wśród państw członkowskich Unii Europejskiej zdecydowanie największy udział w handlu zewnętrznym miały Niemcy. W $2016 \mathrm{r}$. w wywozie towarów z UE-28 do państw trzecich wyniósł on 28,7 \% a w przywozie 18,8\% [EUROSTAT, 2017a].

Na rysunku 1 przedstawiono relatywne zmiany w światowym produkcie brutto, produkcji przemysłowej, handlu światowym i handlu morskim. Od ok. $2000 \mathrm{r}$.

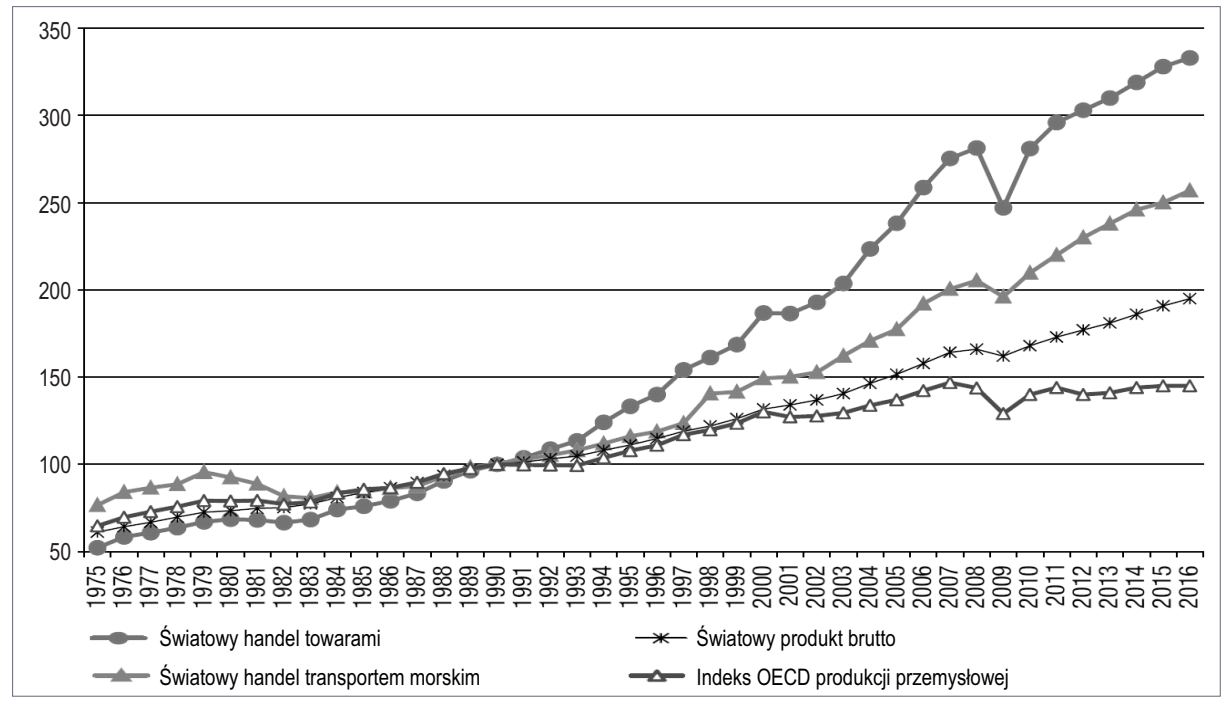

Rysunek 1. Dynamika zmian wolumenu światowego handlu na tle zmian światowego PKB $(1990=100)$

Źródło: [UNCTAD, 2017]. 
obroty handlu światowego i handlu morskiego wzrastały w szybszym tempie niż gospodarka światowa, ale też w 2009 r. zanotowały większy spadek. Globalny eksport spadł w 2009 r. (w relacji do roku wcześniejszego) o 12\% w ujęciu wolumenu, a w ujęciu wartościowym o 23\%. Wysoki spadek wolumenu handlu światowego był większy niż przewidywała większość ekonomistów. Spadek produkcji spowodował zmniejszenie obrotów handlowych i w konsekwencji zapotrzebowanie na usługi transportu morskiego. Jednakże już w 2010 r. straty zostały odrobione [WTO, 2011]. W kolejnych latach wolumen handlu światowego wzrastał w szybkim tempie, ale od 2015 r. obniżała się wartość obrotów handlowych, co ilustrują dane przedstawione na rysunku 2.

Wraz z dynamicznym wzrostem wielkości międzynarodowej wymiany towarowej doszło do istotnych zmian w strukturze towarowej i geograficznej. W handlu międzynarodowym często spotykana jest specjalizacja poszczególnych państw w produkcji określonych dóbr i usług. Kraje dysponujące rozwiniętym przemysłem specjalizują się w eksporcie dóbr wysokoprzetworzonych, o znacznej wartości dodanej (np. Stany Zjednoczone, kraje UE-15, Japonia, Chiny). Wiele krajów słabiej rozwiniętych opiera swój rozwój na wydobywaniu posiadanych bogactw naturalnych lub na prowadzeniu intensywnych upraw rolnych, gdy pozwalają na to warunki naturalne (np. wiele krajów afrykańskich, słabiej rozwinięte kraje azjatyckie). Od pewnego czasu obserwuje się zjawisko przenoszenia produkcji z krajów wysokorozwiniętych o wysokich kosztach pracy do krajów rozwijających się, gdzie koszty pracy są dużo niższe. W krajach o korzystnych warunkach działalności gospodarczej powstają przedsiębiorstwa z udziałem kapitału zagranicznego oraz filie koncernów międzynarodowych. Wymaga to utworzenia sieci kanałów dystrybucji, którymi wyprodukowane dobra wysyłane są do krajów ich konsumpcji. W efekcie tworzą się skomplikowane powiązania wewnątrz przedsiębiorstw międzynarodowych, które wymagają dodatkowych usług zewnętrznych, w tym sprawnego i efektywnego transportu [Nowosielski, 2011].

Kolejnym trendem $\mathrm{w}$ światowej wymianie handlowej jest spadek znaczenia tradycyjnej wymiany o charakterze międzygałęziowym i zwiększanie się udziału wymiany wewnątrzgałęziowej. Handel wewnątrzgałęziowy polega na jednoczesnym imporcie i eksporcie produktów i ich części składowych pochodzących z tej samej gałęzi, dokonywanym przez dany kraj lub grupę krajów [Rynarzewski, 2004, s. 101]. Przedmiotem handlu między partnerami są zatem towary będące bliskimi substytutami w sferze produkcji, konsumpcji lub w obu tych sferach łącznie i są to przemysłowe towary przetworzone. Skutkiem rozwoju handlu wewnątrzgałęziowego jest pogłębienie powiązań gospodarczych między partnerami i przebudowa międzynarodowego podziału pracy [Pawlas, 2017]. Szczególnie wysoki przyrost wymiany wewnątrzgałęziowej miał miejsce $w$ latach dziewięćdziesiątych XX w., a także w początkach XXI w. [Brülhart, 2009]. 
Zachodzące od połowy lat dziewięćdziesiątych XX w. zmiany w geograficznej strukturze handlu międzynarodowego polegały przede wszystkim na systematycznym spadku udziału krajów wysoko rozwiniętych gospodarczo i wzroście udziału krajów rozwijających się, szczególnie Chin, które obecnie są jednym z głównych partnerów handlowych na świecie.

W ostatnich dekadach we współczesnej gospodarce światowej znacznie wzrosła rola usług. Stały wzrost udziału usług w tworzeniu produktu krajowego brutto, zatrudnieniu oraz handlu jest jednym z najistotniejszych trendów rozwojowych zarówno w krajach rozwiniętych, jak i rozwijających się. Najszybciej wzrastają obroty handlowe usługami umożliwiającymi funkcjonowanie globalnych łańcuchów wartości, takimi jak usługi: komunikacyjne, finansowe, komputerowe i informacyjne oraz pozostałe usługi biznesowe [Rudnicka, 2013]. Spostrzeżenie to dotyczy również międzynarodowej wymiany usług (rys. 2).

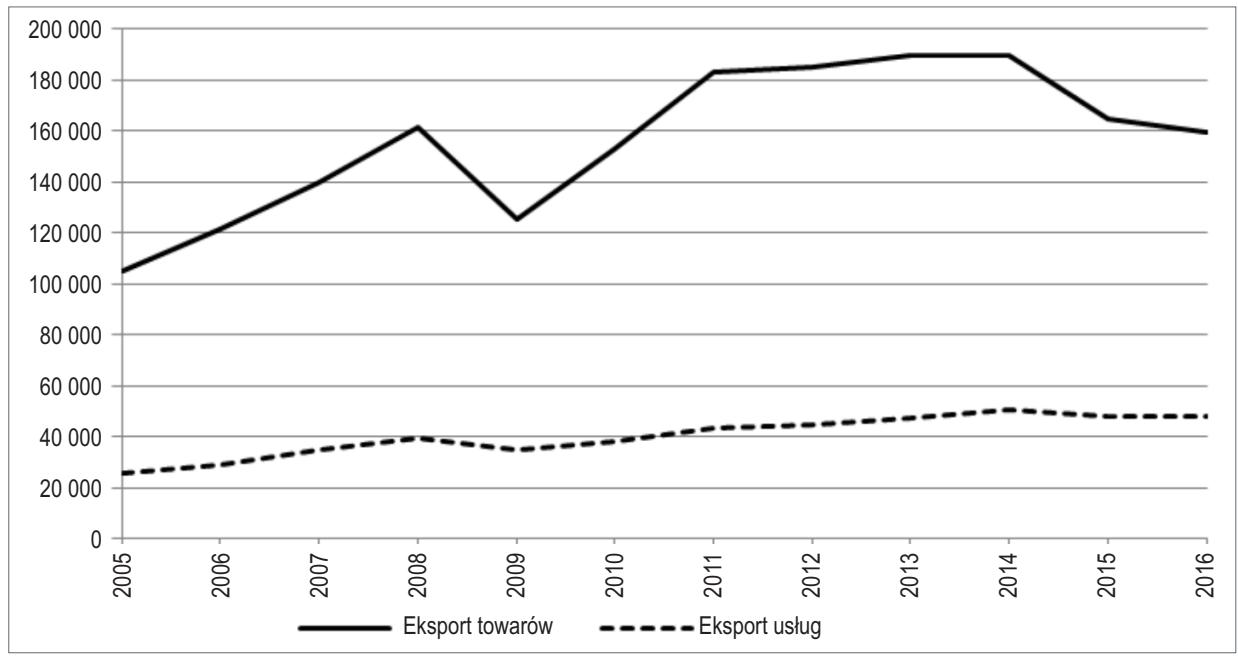

Rysunek 2. Eksport towarów i usług w handlu światowym w latach 2005-2016 (w mld USD, w cenach bieżących)

Źródło: [WTO, 2018].

Na rysunku 2 przedstawiono wielkość eksportu towarów i usług rynkowych w latach 2005-2016. Stosunkowo krótki okres ujęty w tej analizie wynika ze zmiany metodologii klasyfikacji usług, w związku z czym zaprezentowanie danych $z$ lat wcześniejszych nie byłoby metodologicznie poprawne. $Z$ danych wynika, że w latach 2015-2016 zanotowano zarówno spadek wartości eksportowanych towarów, jak i usług, ale spadek eksportu usług nie był tak duży jak towarów i w 2016 r. utrzymał się na podobnym poziomie. Nie dotyczyło to jednak usług transportowych, gdyż w ich przypadku wartość eksportu nadal się obniżała. Na rysunku 3 
została pokazana struktura światowego eksportu w podziale na obroty towarami i usługami rynkowymi.

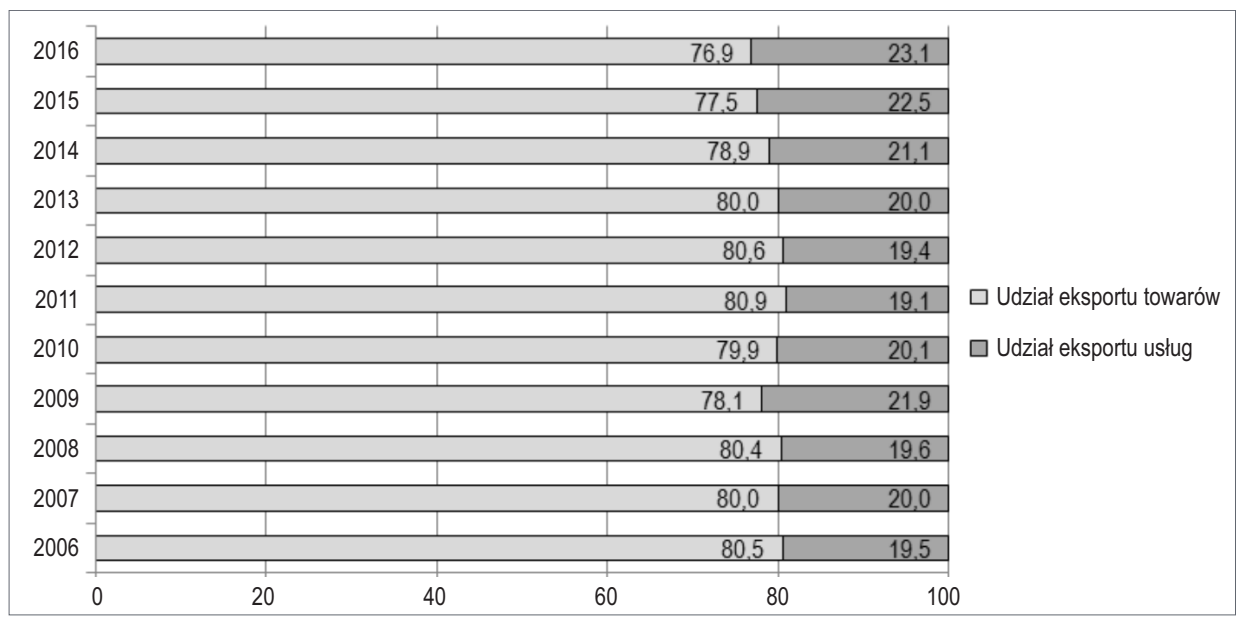

Rysunek 3. Rys. Struktura światowego eksportu w podziale na obroty towarami i usługami $(\mathrm{w} \%)$

Źródło Opracowanie własne na podstawie: [WTO, 2018].

W strukturze światowego eksportu dominuje eksport towarów. W 2016 r. jego udział wyniósł 76,9\%, warto jednak zauważyć, że systematycznie wzrasta udział usług. O ile w 2005 r. udział eksportu usług pozostawał na poziomie poniżej 20\%, to w latach 2006-2016 zwiększył się on o 3,6\%, osiągając wielkość 23,1\%. Z kolei udział importu usług $\mathrm{w}$ imporcie światowym $\mathrm{w}$ tym okresie wahał się $\mathrm{w}$ przedziale 18,3-22,4\%, przy czym dopiero od $2011 \mathrm{r}$. występuje stała tendencja jego wzrostu.

W latach 2006-2016 zwiększyła się wartość usług będących przedmiotem handlu międzynarodowego, mimo spadku w latach 2009 i 2014. Największy udział w handlu międzynarodowym mają podróże i usługi transportowe. W eksporcie usług w 2016 r. wyniósł on odpowiednio $25,1 \%$ oraz $17,7 \%$. Pozostałe rodzaje usług mają znacznie mniejszy udział $\mathrm{w}$ wymianie międzynarodowej i z tego względu często są agregowane w jedną grupę jako "inne usługi rynkowe”. Stanowią one ponad połowę handlu światowego usługami (rys. 4).

$Z$ danych WTO wynika, że usługi transportowe tracą na znaczeniu w handlu międzynarodowym, gdyż ich udział zmniejszył się w badanym okresie o 4,7\% [WTO, 2018], a spadek wartości sprzedaży był największy ze wszystkich rodzajów usług (rys. 5). Mimo że w 2016 r. wartość innych rodzajów usług będących przedmiotem handlu międzynarodowego wzrosła, wartość usług transportowych nadal się obniżała. 


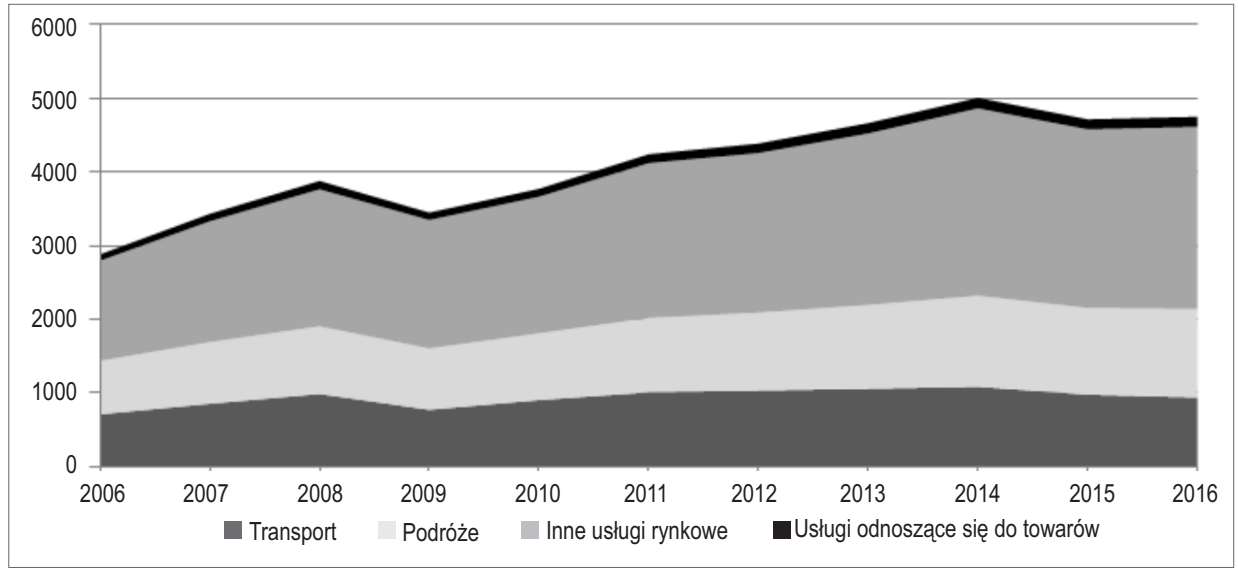

Rysunek 4. Wielkość handlu światowego usługami według rodzaju usług (w mld USD, w cenach bieżących)

Źródło: [WTO, 2018].

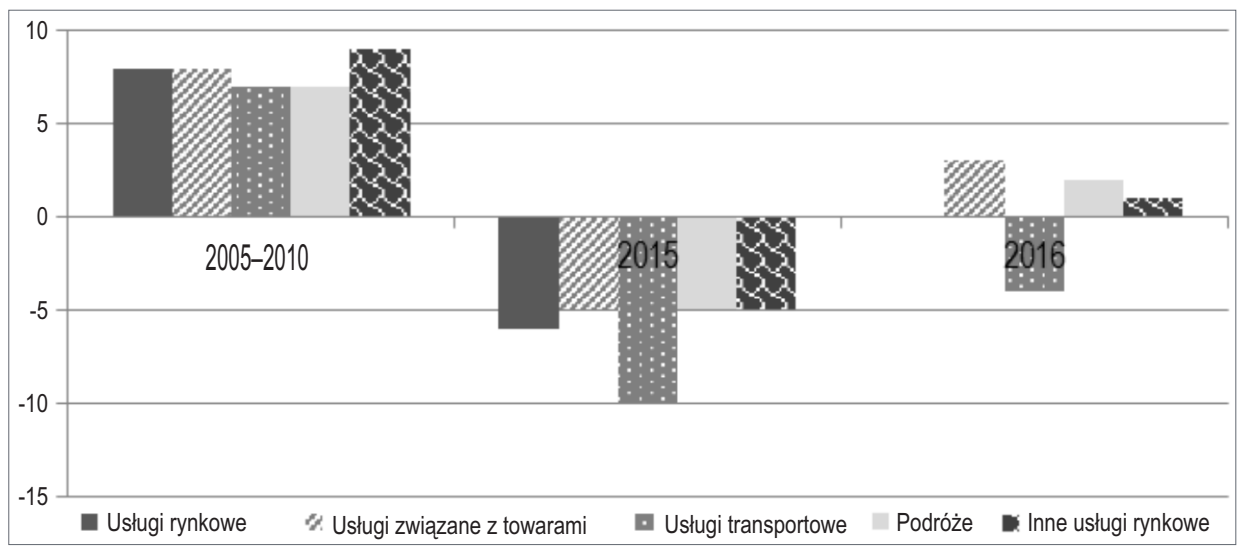

Rysunek 5. Dynamika zmian wartości eksportu usług w handlu światowym Źródło: [WTO, 2018].

\section{Bilans płatniczy Polski}

Bilans płatniczy to statystyczne zestawienie wartości wszystkich transakcji gospodarczych, które miały miejsce między rezydentami danego kraju a nierezydentami (zagranicą) w danym okresie. Pokazuje poziom i strukturę obrotów płatniczych z zagranicą, odzwierciedlając powiązania gospodarki krajowej z gospo- 
darką światową oraz stopień otwarcia gospodarki. Do podstawowych części bilansu płatniczego należą: rachunek obrotów bieżących obejmujący wymianę towarów i usług (import, eksport), dochody majątkowe i przekazy pieniężne, rachunek obrotów kapitałowych (przepływy inwestycji bezpośrednich osób i firm prywatnych oraz przepływy pieniężne) i rachunek zmian rezerw rządowych [NBP, 2018a].

Postępujące procesy globalizacyjne w sferze gospodarczej wywierają istotny wpływ na statystyki polskiego bilansu płatniczego. Obroty z zagranicą mają coraz większy udział w PKB i w coraz większym stopniu decydują o kierunkach polityki gospodarczej. Od kilku lat sytuację płatniczą Polski można uznać za stabilną, o czym świadczy systematycznie obniżający się deficyt rachunku bieżącego, który w 2016 r. wyniósł tylko 5,38 mld PLN (był o ok. połowę mniejszy niż w 2015 r., czterokrotnie mniejszy niż w 2013 r. i jedenastokrotnie mniejszy niż w 2012 r.) [NBP, 2018c]. Natomiast począwszy od 2015 r., zanotowano nadwyżkę w płatnościach wynikających z eksportu i importu towarów. Wcześniej, w pierwszych latach po wejściu do Unii Europejskiej, ujemne saldo obrotów towarowych wzrastało w szybkim tempie ze względu na większą dynamikę wzrostu importu niż eksportu polskich towarów. Występowanie deficytu w rachunku bieżącym oraz strukturalny import kapitału netto są charakterystyczne dla grupy krajów rozwijających się, do których zaliczała się Polska.

Zupełnie inaczej kształtowała się sytuacja w obrocie międzynarodowym usługami, gdyż przez wszystkie lata 2004-2016 saldo wymiany było dodatnie, z tendencją rosnącą (tab. 1). Warto zauważyć, iż w tym okresie udział eksportu usług w łącznej wartości eksportu towarów i usług zwiększył się z 17,2\% do 20,2\% , natomiast udział importu usług pozostawał na stabilnym poziomie $14-15 \%{ }^{1}$. Udział eksportu usług w polskim handlu zagranicznym jest jednak o kilka punktów procentowych niższy niż tendencje ogólnoświatowe. Usługi w bilansie płatniczym obejmują transport wraz z jego ubezpieczeniem, podróże zagraniczne, czyli wydatki cudzoziemców odwiedzających Polskę i Polaków wyjeżdżających za granicę, oraz pozostałe usługi (telekomunikacyjne, budowlane, finansowe, informacyjne, informatycznych itp.). Głównymi partnerami Polski w handlu usługami są Niemcy, Wielka Brytania i Szwajcaria [GUS, 2011-2017].

Transport bierze aktywny udział w międzynarodowej wymianie handlowej i w związku z tym również usługi transportowe i pomocnicze na rzecz transportu są przedmiotem eksportu i importu. Z eksportem polskich usług transportowych mamy do czynienia, gdy [Koźlak, 2010]:

- przewozy eksportowanych lub importowanych towarów są dokonywane przez polskiego przewoźnika własnym taborem, bez względu na to, czy usługa transportowa jest sprzedawana wraz z eksportowanym towarem (gdy gestię

\footnotetext{
1 Obliczenia własne na podstawie danych z tabeli 1.
} 
transportową posiada eksporter), czy też jest to niezależna transakcja sprzedaży usługi transportowej importerowi towaru, mającemu gestię transportową;

- przewoźnik polski wykonuje przewóz ładunków obcych między dwoma innymi krajami (tzw. przewozy cross trade);

- przewoźnik polski wykonuje przewóz ładunków na terytorium innego kraju na rzecz jego obrotu wewnętrznego (przewozy kabotażowe);

- zagraniczny przewoźnik przejeżdża tranzytem przez Polskę lub przez polskie porty morskie (na obszarze Polski nie znajduje się ani początkowy, ani końcowy punkt transportowy).

Tabela 1. Obroty towarowe i usługowe polskiego handlu zagranicznego (w mln PLN)

\begin{tabular}{|c|c|c|c|c|c|c|}
\hline Rok & $\begin{array}{c}\text { Saldo } \\
\text { obrotów to- } \\
\text { warowych }\end{array}$ & Eksport & Import & $\begin{array}{c}\text { Saldo } \\
\text { obrotów } \\
\text { usługami }\end{array}$ & Przychody & Rozchody \\
\hline 2004 & -30233 & 264491 & 294724 & 6173 & 55058 & 48885 \\
\hline 2005 & -17962 & 284034 & 301996 & 7944 & 58873 & 50929 \\
\hline 2006 & -30662 & 334951 & 365613 & 7902 & 69871 & 61969 \\
\hline 2007 & -62172 & 370913 & 433085 & 20119 & 87290 & 67171 \\
\hline 2008 & -82538 & 395358 & 477896 & 17983 & 91458 & 73475 \\
\hline 2009 & -33187 & 412569 & 445756 & 21715 & 97126 & 75411 \\
\hline 2010 & -43677 & 471664 & 515341 & 13174 & 106867 & 93693 \\
\hline 2011 & -54790 & 545586 & 600376 & 21073 & 121189 & 100116 \\
\hline 2012 & -34128 & 590045 & 624173 & 25145 & 133621 & 108476 \\
\hline 2013 & -1345 & 625870 & 627215 & 32070 & 141032 & 108962 \\
\hline 2014 & -13634 & 663891 & 677525 & 37922 & 153753 & 115831 \\
\hline 2015 & 9326 & 720238 & 710912 & 45610 & 170112 & 124502 \\
\hline 2016 & 12834 & 774178 & 761344 & 61428 & 196430 & 135002 \\
\hline
\end{tabular}

Źródło: [NBP, 2018c].

Każdy kraj w mniejszym bądź większym stopniu korzysta z importu usług transportowych. Wiąże się to z koniecznością tranzytu przez terytorium innych państw oraz korzystania z usług przewoźników wybranych przez partnera handlowego, gdy posiada on gestię transportową. Poza usługami przewozowymi przedmiotem eksportu i importu mogą być różne usługi pomocnicze: ubezpieczeniowe, spedycyjne, przeładunkowe, składowania lub usługi świadczone na rzecz obcych środków transportu (np. usługi remontowe, związane z holowaniem, pilotażem, zaopatrywaniem w paliwo, części zamienne itp.).

Transakcje z tytułu dostarczenia i nabycia usług transportowych są ewidencjonowane na rachunku obrotów bieżących w części dotyczącej obrotu usługami. 
Udział eksportu usług transportowych w usługach ogółem wyniósł 26,8\% w 2016 r., a w latach wcześniejszych wahał się w przedziale $26-30 \%$. Natomiast udział importu usług transportowych w imporcie usług ogółem kształtował się na nieco niższym poziomie niż udział eksportu i w latach 2010-2016 było to 20-22\% [GUS, 2011-2017]. Liczby te świadczą o dużym wpływie międzynarodowego obrotu usługami transportowymi na bilans płatniczy usług. Na rysunku 6 przedstawiono zmiany w wysokości przychodów i rozchodów wynikających z międzynarodowego obrotu usługami transportowymi w latach 2004-2016.

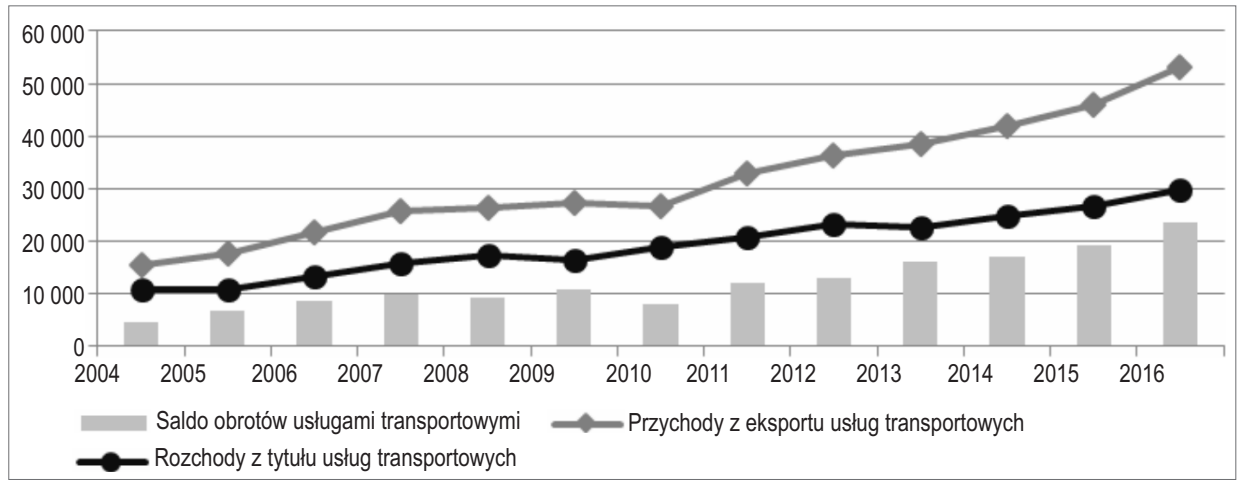

Rysunek 6. Wartość eksportu i importu usług transportowych oraz ich saldo (w mln PLN) Źródło: [NBP, 2018b].

Saldo bilansu usług transportowych w Polsce jest dodatnie, co oznacza, że eksport tych usług przewyższa ich import. Dodatnie saldo usług transportowych i podróży zagranicznych decyduje o tym, że bilans wszystkich usług również jest dodatni. Zarówno przychody z tytułu eksportu usług transportowych, jak i rozchody wynikające $\mathrm{z}$ ich eksportu wykazywały w latach 2004-2016 tendencję rosnącą, przy czym warto zauważyć, iż wzrost przychodów charakteryzował się większą dynamiką, co w rezultacie spowodowało systematyczną poprawę salda bilansu usług transportowych.

W dalszej kolejności warto przeprowadzić analizę udziału poszczególnych gałęzi transportu w eksporcie i imporcie usług transportowych oraz ich wpływu na bilans płatniczy Polski. Szczegółowe dane dotyczące wartości dostarczonych i nabytych usług transportowych przez gałęzie transportu zawiera tabela 2.

Wśród przychodów z eksportu usług transportowych najbardziej znaczącą pozycję stanowią wpływy z transportu samochodowego (ponad 60\%), pozostałych usług wspomagających transport i transportu lotniczego. Równocześnie są to gałęzie transportu, które rozwijają się w Polsce najszybciej. W rozchodach z tytułu importu usług transportowych również transport samochodowy ma największy 


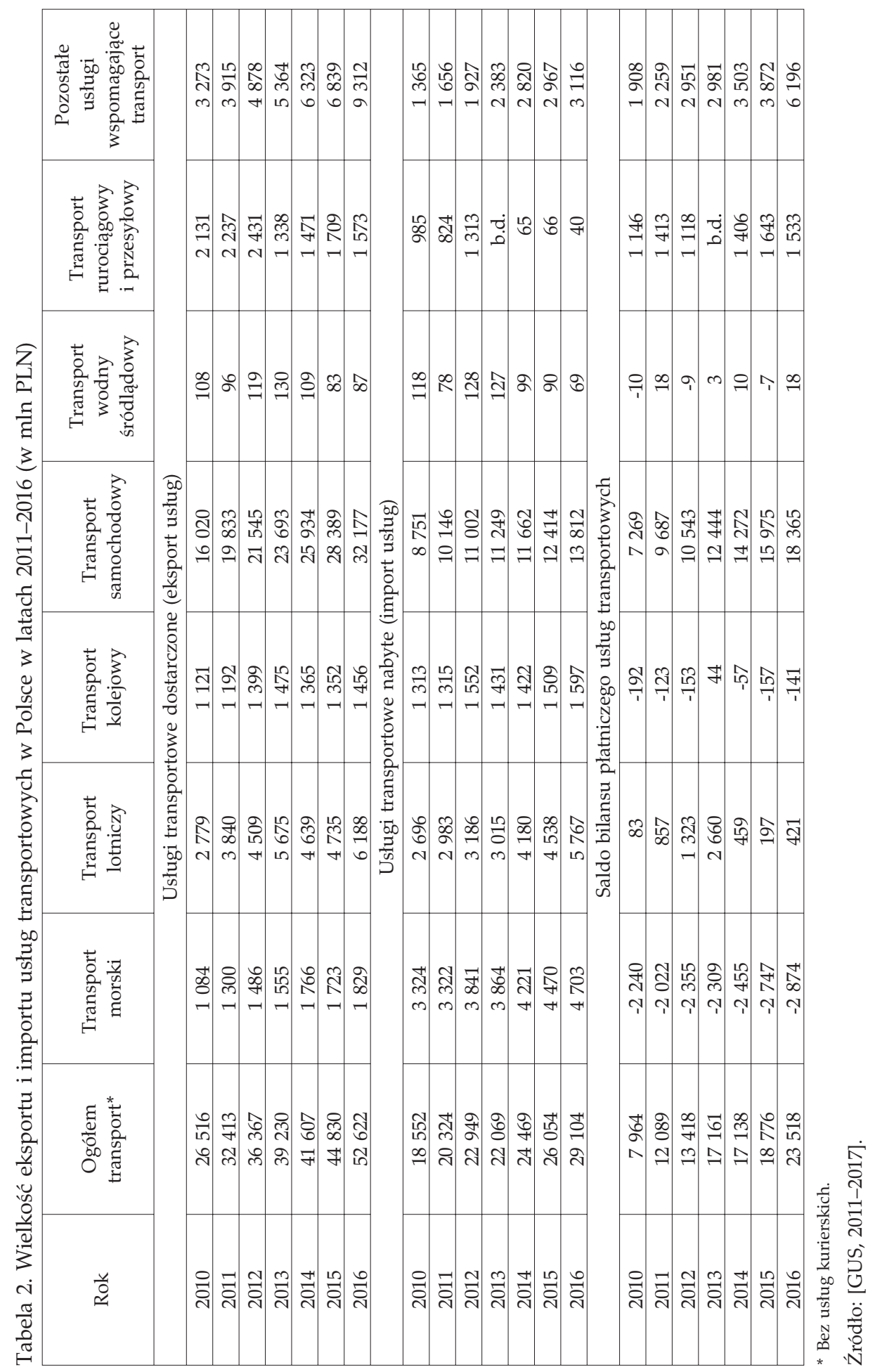


udział, z reguły nie przekracza on jednak 50\%. Kolejnymi dwiema gałęziami transportu pod względem importu usług transportowych są transport lotniczy i morski. Zarówno w eksporcie usług transportowych, jak i imporcie niewielką rolę odgrywa żegluga śródlądowa, co jest skutkiem niskiego poziomu rozwoju tej gałęzi transportu w Polsce i zdegradowanej infrastruktury dróg wodnych.

W 2016 r. saldo usług transportowych wyniosło $23518 \mathrm{mln}$ PLN i było prawie czterokrotnie wyższe niż w 2010 r. Przyczyniło się do tego głównie wysokie dodatnie saldo wymiany usług transportu samochodowego. Wysokie dodatnie saldo występuje również w pozostałych usługach wspomagających transport. Ujemne saldo wymiany usług występuje w transporcie morskim i kolejowym, przy czym najwyższe wartości można zauważyć w transporcie morskim i niestety wykazują one tendencję rosnącą.

\section{Podsumowanie}

Analiza danych zaprezentowanych w pracy pozwoliła na sformułowanie kilku syntetycznych wniosków:

- w latach 1970-2016 dynamika handlu międzynarodowego była znacznie wyższa niż przyrost światowego produktu brutto i w wielu krajach to wzrost eksportu przyczynił się do wzrostu poziomu PKB;

- w strukturze światowego eksportu dominuje eksport towarów, z udziałem ok. 3/4, ale systematycznie wzrasta rola usług; w Polsce również znaczenie usług w handlu zagranicznym wzrasta, ale ich udział w obrotach jest o kilka punktów procentowych niższy;

- usługi transportowe tracą na znaczeniu w handlu światowym, o czym świadczy spadek obrotów usługami transportowymi i zmniejszenie się ich udziału w eksporcie usług o 4,7\%; w Polsce tendencja jest odwrotna, tzn. wzrasta eksport i import usług transportowych;

- udział eksportu usług transportowych w usługach ogółem w Polsce jest o ponad 10\% większy niż w skali ogólnoświatowej;

- w latach 2004-2016 saldo bilansu płatniczego w części dotyczącej wymiany międzynarodowej usług było w Polsce dodatnie, $\mathrm{z}$ tendencją rosnącą, co w pewnym stopniu zmniejszało negatywne skutki ujemnego salda wymiany towarowej; dopiero od 2015 r. notuje się dodatnie saldo bilansu również w obrotach towarami;

- systematycznie zwiększało się dodatnie saldo bilansu usług transportowych, do czego przyczyniał się głównie transport samochodowy i usługi pomocnicze na rzecz transportu. 
Obserwacje te pozwalają stwierdzić, iż usługi transportowe wywierają istotny wpływ na kształtowanie się struktury i salda rachunku obrotów bieżących polskiego bilansu płatniczego. Wzrastający eksport usług transportowych, szczególnie transportu samochodowego, przyczynia się do uzyskiwania dodatniego salda bilansu płatniczego i może świadczyć o wykształceniu się specjalizacji eksportowej. Potwierdzają to inne badania przeprowadzone przez autorkę, które wykazały wysoką konkurencyjność polskich przewoźników drogowych na rynku europejskim, mających udział w przewozach międzynarodowych na poziomie $28,2 \%$ [EUROSTAT, 2017b].

Bibliografia

Brülhart M., 2009, An Account of Global Intra-industry Trade 1962-2006, The World Economy, vol. 32, issue 3 .

EUROSTAT, 2017a, Międzynarodowy handel towarami, Statistics Explained, http://ec.europa. $\mathrm{eu} /$ eurostat/statistics-explained/index.php/International_trade_in_goods/pl [dostęp: 10.02.2018].

EUROSTAT, 2017b, Road freight transport by journey characteristics, Statistics Explained, http://ec.europa.eu/eurostat/statistics-explained/index.php/Road_freight_transport_ by_journey_characteristics [dostęp: 22.02.2018].

GUS, 2011-2017, Roczniki statystyczne handlu zagranicznego, Główny Urząd Statystyczny, Warszawa.

Jaszczyński M., 2016, Znaczenie handlu zagranicznego w rozwoju gospodarczym, Zeszyty Naukowe PWSZ w Płocku, Nauki Ekonomiczne, t. 23.

Koźlak A., 2010, Ekonomika transportu. Teoria i praktyka gospodarcza, Wydawnictwo Uniwersytetu Gdańskiego, Gdańsk.

NBP, 2018a, Stownik, https://www.nbportal.pl/slownik/pozycje-slownika/bilans-platniczy [dostęp: 22.02.2018].

NBP, 2018b, Statystyka bilansu ptatniczego, Bilans ptatniczy - dane kwartalne, http://www.nbp. pl/statystyka/bilans_platniczy/bop_q_pln.xlsx [dostęp: 22.02.2018].

NBP, 2018c, Statystyka bilansu ptatniczego, Bilans ptatniczy - dane roczne, http://www.nbp.pl/ statystyka/bilans_platniczy/bop_y.xlsx [dostęp: 22.02.2018].

Nowosielski T., 2011, Funkcjonowanie transportu morskiego w warunkach globalizacji, Współczesna Gospodarka, vol. 2, issue 1.

Pawlas I., 2017, Relacje handlowe Polski ze Stanami Zjednoczonymi w latach 2006-2015, [w:] Handel zagraniczny ibiznes międzynarodowy we wspótczesnej gospodarce, red. M. Maciejewski, K. Wach, Uniwersytet Ekonomiczny w Krakowie, Kraków.

Rogaczewski R., 2017, Wybrane aspekty handlu międzynarodowego na przykładzie Polski i Niemiec, Acta Universitatis Nicolai Copernici. Zarządzanie, vol. 44, no. 2.

Rudnicka M., 2013, Globalne tendencje w handlu ustugami, Prace Naukowe Uniwersytetu Ekonomicznego we Wrocławiu, $\mathrm{nr} 315$.

Rynarzewski T. (red.), 2004, Teoria handlu międzynarodowego a wspótczesna gospodarka światowa, Wydawnictwo Akademii Ekonomicznej w Poznaniu, Poznań.

UNCTAD, 2017, Review of maritime transport 2017, New York - Geneva.

UNCTADSTAT, 2018, http://unctadstat.unctad.org [dostęp: 20.02.2018]. 
WTO, 2011, International Trade Statistics 2011, https://www.wto.org/english/res_e/statis_e/ its2011_e/its11_toc_e.htm [dostęp: 20.02.2018].

WTO, 2018, Statistics database, http://stat.wto.org/Home/WSDBHome.aspx?Language=E [dostęp: 20.02.2018].

A. Koźlak (®) a.kozlak@ug.edu.pl Wydział Ekonomiczny, Uniwersytet Gdański, ul. Armii Krajowej 119/121, 81-824 Sopot, Polska 